\title{
APAKAH PENGETAHUAN DAN SIKAP MENJADI KONTRIBUTOR UTAMA DALAM PEMBENTUKAN PERILAKU PENGGUNAAN PEMBALUT PADA REMAJA PUTRI DI DAERAH PEDESAAN KABUPATEN PANGKEP?
}

\author{
Rosmina $^{1 *}$, Safrullah Amir ${ }^{2}$, Badaruddin $^{3}$, Ahdy Syafar $^{4}$ \\ 1. Faculty of Health, Universitas Islam Makassar, Makassar, 90245, Indonesia \\ 2. Faculty of Medicine, Universitas Gadjah Mada, Yogyakarta, 55598, Indonesia \\ 3. Islam Faisal Hospital, Makassar, 90222, Indonesia \\ 4. Region Hospital of Haji, Makassar, 90224, Indonesia
}

*E-mail: rosmina@merahputih.id

\begin{abstract}
Abstrak
Penggunaan pembalut yang kurang tepat dapat berimplikasi pada terjadinya berbagai masalah kesehatan reproduksi. Perilaku penggunaan pembalut diinisiasi oleh domain pengetahuan dan sikap. Remaja putri merupakan kelompok paling rentan dimana terdapat kecenderungan mengembangkan stigma negatif terhadap menstruasi sehingga berimbas pada kekurangterpaparan terhadap informasi higienitas menstruasi. Penelitian ini dikembangkan untuk mengonfirmasi pengetahuan dan sikap dalam menginisiasi pembentukan perilaku penggunaan pembalut pada remaja putri di daerah pedesaan. Jenis penelitian yang digunakan adalah observasional analitik dengan rancangan cross-sectional. Pemilihan lokasi dan sampel penelitian ditentukan secara purposive dengan memasukkan seluruh siswi Sekolah Menengah Pertama Negeri X Tondong Tallasa yang telah mengalami menstruasi. Hasil penelitian menunjukkan remaja putri memiliki pengetahuan, sikap, dan perilaku penggunaan pembalut yang masih kurang dengan persentase berturut-turut $57,45 \%$, $57,45 \%$, dan $70,21 \%$. Temuan lain dalam penelitian ini mengindikasikan adanya perbedaan perilaku penggunaan pembalut pada remaja putri menurut pengetahuan dan sikap. Meskipun demikian, tidak ditemukan adanya signifikansi pengetahuan dan sikap dalam perilaku penggunaan pembalut pada responden $(p>0,05)$. Kesimpulan dalam penelitian ini adalah pengetahuan dan sikap tidak menunjukkan asosiasi dengan perilaku penggunaan pembalut pada remaja putri di daerah pedesaan. Pada penelitian berikutnya diharapkan menyertakan variabel kontributor yang lain dengan melibatkan jumlah sampel yang lebih besar.
\end{abstract}

Kata Kunci: menstruasi, pembalut, pengetahuan, perilaku, remaja putri, sikap

\section{Abstract}

Are Knowledge and Attitude Being Main Contributors in Shaping Behavior of Pad Use among Female Adolescents in Rural Pangkep District? Inappropriate use of pads may lead to various reproductive health problems. Behavior of pad use is initiated by knowledge and attitude domain. Female adolescents are the most vulnerable group in which there is a tendency to develop negative stigma against menstruation so that impact on lack of exposure to the menstrual hygiene information. This study aims to determine association between knowledge and attitude in shaping behavior of pad use among female adolescents in rural. The type of research used was analytic observational with cross-sectional design. Location and sample of the study were determined purposively by taking all students of SMPN X Tondong Tallasa who have experienced menstruation. This study found that female adolescents still had poor knowledge, attitudes, and behaviors in pad use with a percentage of 57,45\%,57,45\%, and 70,21\% respectively. Other findings in this study showed there was difference in behavior of pad use in female adolescents according to knowledge and attitude. Nevertheless, there was no significance of knowledge and attitude in the behavior of pad use on respondents ( $p>0,05)$. Conclusions in this study found that knowledge and attitudes do not show association with behavior of pad use in female adolescents in rural area. In the next study, it is expected to include other contributory variables by involving larger sample size.

Keywords: attitude, behavior, female adolescent, knowledge, menstruation, pad 


\section{Pendahuluan}

Menstruasi atau haid adalah suatu keadaan yang lazim dialami oleh setiap perempuan yang berada dalam masa reproduksi. Hal tersebut ditandai dengan timbulnya noda berupa darah kotor yang keluar dari mulut vagina (Rahayu, 2010). Peristiwa ini akan dialami oleh perempuan setiap 21-35 hari dengan periode waktu mencapai 2-8 hari (Andriyani, 2013).

Darah kotor yang keluar selama fase menstruasi berpotensi meleleh kemana-mana dan terkadang menimbulkan bau yang tidak sedap. Hal ini mendasari sebagian besar perempuan memilih pembalut sebagai alternatif solusi untuk menahan rembesan darah haid. Kondisi ini menjadikan pembalut seakan menjadi kebutuhan pokok bagi kaum perempuan. Terbukti dari hasil observasi menunjukkan penggunaan pembalut mencapai 1,4 miliar setiap bulan dengan jumlah pengguna lebih kurang 71.566.684 perempuan (YLKI, 2015).

Pada dasarnya sebuah produk pembalut wanita harus bersih dan tidak mengandung zat berbahaya. Hal ini mempertimbangkan terjadi kontak langsung antara pembalut dengan area intim perempuan. Namun, hal ini kontradiktif dengan hasil uji laboratorium yang dilakukan Yayasan Lembaga Konsumen Indonesia (YLKI) pada 7 Juli 2015. Hasil uji laboratorium terhadap pembalut dan pantyliner pada sembilan merek menunjukkan adanya kandungan klorin dengan kadar yang sangat tinggi mencapai 6-55 ppm. Sementara klorin dalam kadar yang tinggi dianggap sangat berbahaya bagi kesehatan reproduksi perempuan karena bersifat iritatif bahkan karsinogenik (YLKI, 2015).

Tidak hanya komposisi pembalut yang mengancam keamanan pengguna, pemakaian yang kurang tepat turut memberikan kontribusi negatif. Pembalut umumnya diproduksi dengan alat penyerap yang aman dengan penggantian empat sampai lima kali dalam sehari bahkan dengan volume darah yang banyak proses penggantian akan lebih sering. Pembalut de- ngan frekuensi penggantian yang jarang lebih cenderung memberikan efek kering yang tidak alamiah pada vagina yang berpotensi menjadikan vagina lebih rentan terhadap infeksi (Kusmiran, 2011).

Penggunaan pembalut yang kurang tepat menyebabkan kerentanan terhadap organ genitalia. Pada kondisi menstruasi, organ genitalia sangat mudah mengalami infeksi disebabkan masuknya kuman melalui saluran reproduksi (Kusmiran, 2011). Kebersihan pembalut yang kurang baik dapat menjadi pemicu munculnya infeksi, iritasi, vaginitis (radang vagina) bahkan akumulasi dalam jangka waktu yang lama dapat memicu terjadinya kanker serviks. Penggunaan produk pembalut yang tidak berkualitas meningkatkan risiko terjadinya kanker serviks hingga 2,3 kali (Syatriani, 2011).

\section{Pada 2012 World Health Organization (WHO)} merilis laporan prevalensi global kanker serviks. Dalam laporan tersebut disebutkan bahwa kanker serviks merupakan kanker dengan jumlah penderita terbesar kedua setelah kanker payudara yang diderita kaum perempuan. Di negara berkembang, insidensi kasus kanker serviks mencapai 528.000 kasus dengan angka kematian sebanyak 266.000 perempuan (WHO, 2014). Berdasarkan sebaran wilayah, Indonesia merupakan negara dengan penderita kanker serviks tertinggi di dunia (Himawati \& Sahara, 2016).

Survei yang dilakukan dalam Riset Kesehatan Dasar (Riskesdas) pada tahun 2013 melibatkan 98.692 penderita kanker serviks. Secara nasional, prevalensi kanker serviks mencapai $0,8 \%$. Sementara itu, menurut hasil sebaran provinsi, Sulawesi Selatan memiliki prevalensi kanker serviks yang sama dengan prevalensi nasional (Balitbangkes, 2013).

Tingginya insidensi kanker serviks mendorong pemerintah Kabupaten Pangkep secara aktif menggalakkan deteksi dini kanker serviks. Hal ini disebabkan oleh investigasi terhadap sepuluh jenis penyakit penyebab kematian di 
Kabupaten Pangkep pada 2013 menempatkan kanker dalam urutan ke delapan. Hal ini mengindikasikan masih dibutuhkan upaya serius dalam aspek preventif dan promotif untuk menanggulangi insidensi penyakit kanker. Salah satunya yaitu prevensi kejadian kanker serviks secara dini melalui edukasi penggunaan pembalut yang benar (Dinkes Kabupaten Pangkep, 2014).

Kecemasan menjadi faktor utama kurang terpaparnya remaja putri terhadap informasi tentang menstruasi. Seringkali tumbuh keyakinan bahwa menstruasi merupakan sesuatu yang tidak menyenangkan untuk dibicarakan. Dengan kata lain, remaja putri mengembangkan sikap negatif terhadap menstruasi. Mereka cenderung merasa malu dan melihatnya sebagai suatu penyakit. Hal ini mengindikasikan remaja putri memiliki sikap dan pengetahuan yang masih rendah terkait manajemen dalam menghadapi menstruasi yang pada akhirnya berimbas pada penggunaan pembalut yang kurang tepat (Manuaba, Manuaba, \& Manuaba, 2015).

Sikap introvert yang ditunjukkan remaja putri berpotensi menyebabkan kurang memadainya pengetahuan dan sikap yang bermuara pada perilaku penggunaan pembalut yang kurang tepat. Hal ini mendasari dilakukannya penelitian ini untuk mengobservasi keterkaitan pengetahuan dan sikap dengan perilaku penggunaan pembalut pada remaja putri di daerah pedesaan Kabupaten Pangkep.

\section{Metode}

Jenis penelitian yang digunakan adalah observasional analitik dengan desain cross-sectional. Pendekatan cross-sectional bertujuan menggambarkan hubungan pengetahuan dan sikap dengan perilaku penggunaan pembalut pada remaja putri dalam satu waktu.

Penelitian ini dilaksanakan pada Agustus 2017 di SMP Negeri X Tondong Tallasa Kabupaten Pangkep dengan melibatkan seluruh siswi (total sampling) yang memenuhi kriteria inklusi dan eksklusi yang ditetapkan sebagaimana ditunjukkan pada Gambar 1. Kriteria inklusi dalam penelitian ini, yaitu siswi yang telah mengalami menstruasi dan bersedia dijadikan responden. Sementara kriteria eksklusi yang membatasi tidak diikutsertakannya calon responden dalam penelitian ini, yaitu siswi tidak masuk sekolah atau dalam keadaan sakit selama penelitian berlangsung dan data responden tidak lengkap atau kurang logis.

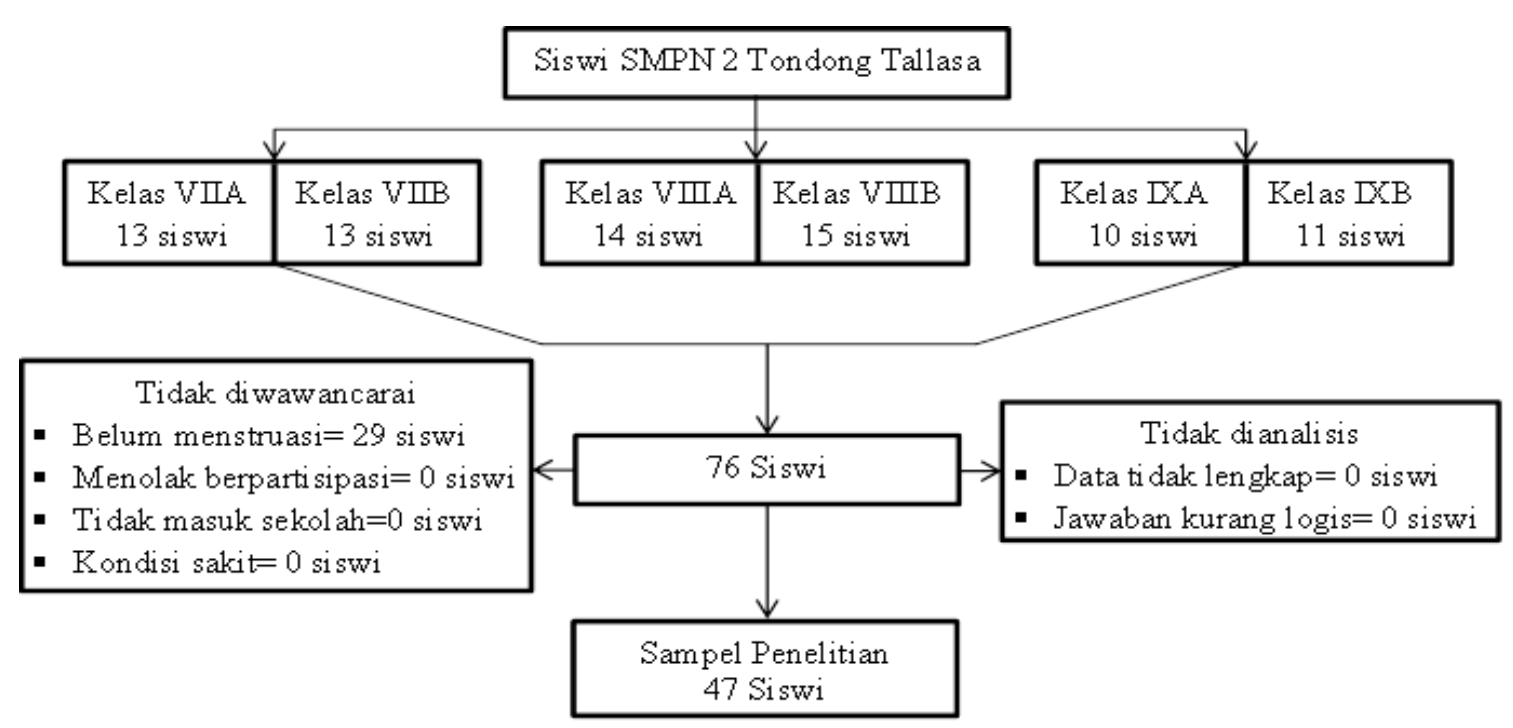

Gambar 1. Bagan Penarikan Sampel 


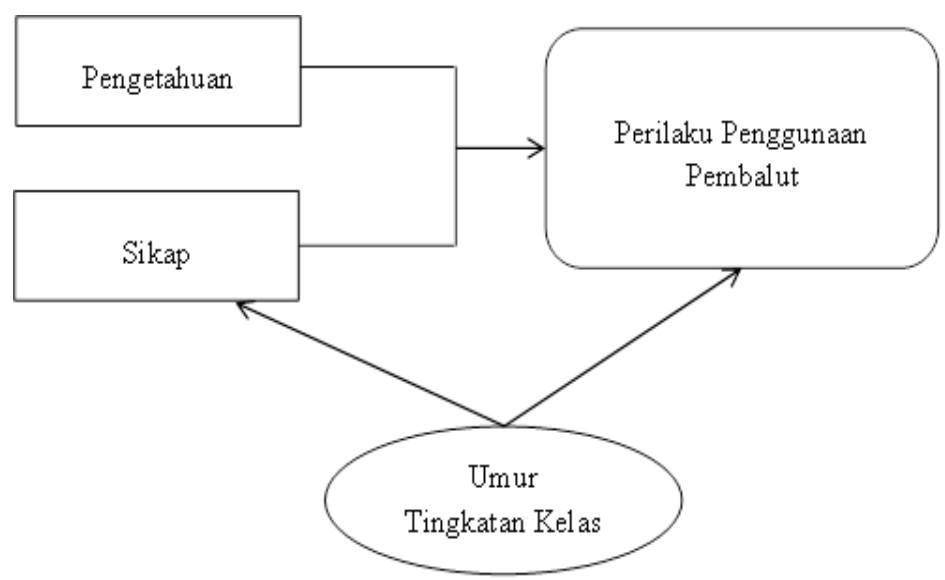

Gambar 2. Kerangka Konsep

Variabel dalam penelitian ini terbagi menjadi 3, yaitu variabel independen, variabel dependen, dan variabel luar sebagaimana ditunjukkan pada Gambar 2. Variabel pengetahuan dan perilaku penggunaan pembalut diukur dengan menggunakan skala guttman, sedang variabel sikap diukur dengan menggunakan skala likert. Penentuan kriteria objektif pada variabel utama penelitian dilakukan menggunakan metode statistik normatif dengan menggunakan nilai median sebagai acuan dalam kategorisasi variabel menjadi kurang dan cukup.

Data yang dikumpulkan terdiri dari data primer dan data sekunder. Data primer dikumpulkan dengan menggunakan kuesioner dalam bentuk pertanyaan tertutup. Sementara data sekunder diperoleh dengan menelusuri database SMPN X Tondong Tallasa untuk memperoleh karakteristik subjek yang berhubungan dengan penelitian.

Pengolahan data penelitian dilakukan secara univariat dan bivariat dengan menggunakan program STATA. Analisis univariat bertujuan menggambarkan karakteristik responden yang dilakukan dengan menggunakan distribusi frekuensi. Analisis bivariat yang digunakan dalam penelitian ini adalah uji Chi-Square dengan alternatif uji Fisher serta uji Independent t-test dengan alternatif uji Mann-Whitney. Tingkat kepercayaan ditetapkan sebesar $95 \%$ dengan nilai signifikansi kurang dari $0,05(\mathrm{p}<0,05)$.
Persetujuan etik dalam penelitian diperoleh dengan mengajukan surat permohonan untuk mendapatkan rekomendasi dan kelayakan penelitian dari Fakultas Ilmu Kesehatan Universitas Islam Makassar (FIK-UIM). Setelah melalui uji kelayakan, proses perizinan berikutnya dilakukan melalui Unit Pelaksana Teknis Pelayanan Perizinan Terpadu Badan Koordinasi Penanaman Modal Daerah (UPT-P2T BKPMD) Provinsi Sulawesi Selatan, Pemerintah Kabupaten Pangkep dalam hal ini Kesatuan Bangsa dan Politik Daerah (Kesbangda) Kabupaten Pangkep, Dinas Pendidikan Kabupaten Pangkep, Dinas Kesehatan Kabupaten Pangkep, dan Kepala Sekolah SMPN X Tondong Tallasa. Dalam proses pelaksanaan penelitian terdapat penekanan pada aspek etika yang meliputi penjelasan secara komprehensif terkait penelitian sebelum distribusi lembar informed consent serta penerapan aspek anonimity dan confidentiallity secara ketat dalam pengumpulan data.

\section{Hasil}

Karakteristik Responden. Responden dalam penelitian ini merupakan remaja putri yang sedang menjalani pendidikan di SMP Negeri $X$ Tondong Tallasa. Sebanyak 47 responden yang memenuhi kriteria inklusi dan eksklusi diikutsertakan dalam penelitian ini. Karakteristik responden meliputi umur, kelas, pengetahuan, sikap, dan perilaku penggunaan pembalut disajikan dalam Tabel 1. 
Berdasarkan identifikasi distribusi frekuensi yang disajikan pada Tabel 1 terlihat bahwa sebagian besar responden penelitian berada pada rentang umur $13-14$ tahun $(72,3 \%)$ dengan umur termuda 11 tahun $(2,13 \%)$ dan tertua 15 tahun $(17,02 \%)$. Sementara itu, sebaran responden yang telah mengalami menstruasi menurut tingkatan kelasnya terbanyak pada kelas IX $(40,4 \%)$.

Analisis univariat pada variabel utama penelitian dilakukan dengan tujuan memperoleh gambaran tingkat pengetahuan, sikap, dan perilaku responden dalam penggunaan pembalut. Hasil analisis menunjukkan baik pengetahuan, sikap, maupun perilaku penggunaan pembalut responden sebagian besar berada pada kategori kurang dengan persentase berturut turut sebesar $57,4 \%$ pada variabel pengetahuan dan sikap serta $70,2 \%$ pada variabel perilaku penggunaan pembalut.

Gambaran Pengetahuan, Sikap, dan Perilaku Penggunaan Pembalut Berdasarkan Karakteristik Responden. Data dasar yang berhubungan dengan karakteristik responden dimanfaatkan untuk melakukan tabulasi silang dengan variabel pengetahuan, sikap, dan perilaku dalam penggunaan pembalut. Karakteristik responden berupa umur dan tingkatan kelas dianalisis secara bivariat dengan variabel utama penelitian dengan hasil sebagaimana ditunjukkan pada Tabel 2 dan 3.

Merujuk Tabel 2, terdapat perbedaan bermakna nilai mean pengetahuan dan median sikap responden menurut umur $(\mathrm{p}<0,05)$. Hal ini megindikasikan adanya kecenderungan semakin bertambahnya umur responden, maka semakin baik pula pengetahuan dansikap dalam penggunaan pembalut. Namun, kecenderungan tersebut tidak berlaku pada variabel perilaku penggunaan pembalut. Hal ini dibuktikan tidak ditemukannya perbedaan yang signifikan pada nilai mean antara responden yang berada pada kategori perilaku kurang dan cukup berdasarkan umur.

Karakteristik responden lain yang dikompilasi adalah tingkatan kelas. Tingkatan kelas dianalisis secara bivariat dengan variabel pengetahuan, sikap, dan perilaku penggunaan pembalut menggunakan uji Chi-Square dengan hasil sebagaimana ditunjukkan pada Tabel 3.

Tabel 1. Karakteristik Responden

\begin{tabular}{|c|c|c|}
\hline Variabel & $\mathbf{n}$ & $\%$ \\
\hline \multicolumn{3}{|l|}{ Umur $^{2}$} \\
\hline 11 tahun & 1 & 2,13 \\
\hline 12 tahun & 4 & 8,51 \\
\hline 13 tahun & 18 & 38,3 \\
\hline 14 tahun & 16 & 34,04 \\
\hline 15 tahun & 8 & 17,02 \\
\hline \multicolumn{3}{|l|}{ Kelas $^{2}$} \\
\hline VII & 10 & 21,28 \\
\hline VIII & 18 & 38,3 \\
\hline IX & 19 & 40,43 \\
\hline \multicolumn{3}{|l|}{ Pengetahuan $^{1}$} \\
\hline Kurang & 27 & 57,45 \\
\hline Cukup & 20 & 42,55 \\
\hline \multicolumn{3}{|l|}{ Sikap $^{1}$} \\
\hline Kurang & 27 & 57,45 \\
\hline Cukup & 20 & 42,55 \\
\hline \multicolumn{3}{|c|}{ Perilaku Penggunaan Pembalut ${ }^{1}$} \\
\hline Kurang & 33 & 70,21 \\
\hline Cukup & 14 & 29,79 \\
\hline
\end{tabular}

(Sumber: ${ }^{1}$ Data Primer $\&^{2}$ Data Sekunder, 2017) 
Tabel 2. Gambaran Pengetahuan, Sikap, dan Perilaku Penggunaan Pembalut Berdasarkan Umur

\begin{tabular}{|c|c|c|c|c|c|c|c|c|c|}
\hline & \multicolumn{2}{|c|}{ Pengetahuan } & \multirow[b]{2}{*}{$\mathbf{p}^{*}$} & \multicolumn{2}{|c|}{ Sikap } & \multirow[b]{2}{*}{$\mathbf{p}^{* *}$} & \multicolumn{2}{|c|}{ Perilaku } & \multirow[b]{2}{*}{$\mathbf{p}^{*}$} \\
\hline & $\begin{array}{c}\text { Kurang } \\
(\mathrm{n}=27)\end{array}$ & $\begin{array}{l}\text { Cukup } \\
(\mathrm{n}=20)\end{array}$ & & $\begin{array}{c}\text { Kurang } \\
(\mathrm{n}=27)\end{array}$ & $\begin{array}{l}\text { Cukup } \\
(\mathrm{n}=20)\end{array}$ & & $\begin{array}{c}\text { Kurang } \\
(\mathrm{n}=33)\end{array}$ & $\begin{array}{l}\text { Cukup } \\
(\mathrm{n}=14)\end{array}$ & \\
\hline Umur & $13,3(0,19)$ & $13,9(0,18)$ & 0,0298 & $13(12-15)$ & $14(11-15)$ & 0,0035 & $13,5(0,16)$ & $13,7(0,27)$ & 0,4555 \\
\hline
\end{tabular}

(Sumber: Data Primer, 2017)

Keterangan: *Uji Independent $t$-test with equal variances, nilai signifikansi $\mathrm{p}<0,05$

**Uji Mann-Whitney, Pengetahuan dan perilaku disajikan dalam rerata (simpang baku), sikap disajikan dalam median (minimum-maksimum)

Tabel 3. Gambaran Pengetahuan, Sikap, dan Perilaku Penggunaan Pembalut Berdasarkan Tingkatan Kelas

\begin{tabular}{|c|c|c|c|c|c|c|c|c|c|c|c|c|c|c|c|}
\hline \multirow{3}{*}{ Kelas } & \multicolumn{4}{|c|}{ Pengetahuan } & \multirow{3}{*}{$\mathbf{p}$} & \multicolumn{4}{|c|}{ Sikap } & \multirow{3}{*}{$\mathbf{p}$} & \multicolumn{4}{|c|}{ Perilaku } & \multirow{3}{*}{$\mathbf{P}$} \\
\hline & \multicolumn{2}{|c|}{ Kurang } & \multicolumn{2}{|c|}{ Cukup } & & \multicolumn{2}{|c|}{ Kurang } & \multicolumn{2}{|c|}{ Cukup } & & \multicolumn{2}{|c|}{ Kurang } & \multicolumn{2}{|c|}{ Cukup } & \\
\hline & $\mathbf{N}$ & $\%$ & $\mathbf{n}$ & $\%$ & & $\mathbf{n}$ & $\%$ & $\mathbf{n}$ & $\%$ & & $\mathbf{n}$ & $\%$ & $\mathbf{n}$ & $\%$ & \\
\hline VII & 10 & 100 & 0 & 0 & & 9 & 90 & 1 & 10 & & 6 & 60 & 4 & 40 & \\
\hline VIII & 10 & 55,6 & 8 & 44,5 & 0,005 & 13 & 72,2 & 5 & 27,8 & 0,001 & 15 & 83,3 & 3 & 16,7 & 0,296 \\
\hline IX & 7 & 36,8 & 12 & 63,2 & & 5 & 26,3 & 14 & 73,7 & & 12 & 63,2 & 7 & 36,8 & \\
\hline
\end{tabular}

(Sumber: Data Primer, 2017)

Keterangan: Uji Chi-Square, nilai signifikansi $\mathrm{p}<0,05$

Tabel 4. Hubungan Pengetahuan dan Sikap dengan Perilaku Penggunaan Pembalut

\begin{tabular}{|c|c|c|c|c|c|}
\hline \multirow{3}{*}{ Variabel } & \multicolumn{5}{|c|}{ Perilaku Penggunaan Pembalut } \\
\hline & \multicolumn{2}{|c|}{ Kurang } & \multicolumn{2}{|c|}{ Cukup } & \multirow{2}{*}{$\mathbf{p}^{*}$} \\
\hline & $\mathbf{n}$ & $\%$ & $\mathbf{n}$ & $\%$ & \\
\hline \multicolumn{6}{|l|}{ Pengetahuan } \\
\hline Kurang & 20 & 74,07 & 7 & 25,93 & 0,501 \\
\hline Cukup & 13 & 65 & 7 & 35 & \\
\hline \multicolumn{6}{|l|}{ Sikap } \\
\hline Kurang & 20 & 74,07 & 7 & 25,93 & 0,501 \\
\hline Cukup & 13 & 65 & 7 & 35 & \\
\hline
\end{tabular}

(Sumber: Data Primer, 2017)

Keterangan: Uji Chi-Square, nilai signifikansi p $<0,05$

Sama halnya dengan umur responden, tingkatan kelas hanya menunjukkan hubungan yang signifikan dengan variabel pengetahuan dan sikap dalam penggunaan pembalut $(\mathrm{p}<0,05)$. Interpretasi hasil analisis pada Tabel 3 menunjukkan proporsi pengetahuan, sikap, dan perilaku penggunaan pembalut lebih baik pada responden yang berada pada tingkatan kelas yang lebih atas dibandingkan responden yang berada pada tingkatan kelas terbawah. Meskipun demikian, pada variabel perilaku penggunaan pembalut tidak menemui hasil yang signifikan secara statistik.

\section{Hubungan Sikap dengan Perilaku Peng-} gunaan Pembalut. Kategori variabel sikap dan perilaku ditabulasi silang untuk melihat proporsi dan kemaknaannya sebagaimana disajikan dalam Tabel 4. Merujuk pada hasil analisis, tidak ditemukan ada signifikansi antara pengetahuan dan sikap responden dengan perilaku dalam penggunaan pembalut. Namun, te- 
laah lebih mendalam mengindikasikan adanya perbedaan proporsi sikap responden yang kurang dan cukup dalam perilaku penggunaan pembalut. Berdasar Tabel 4 dapat disimpulkan bahwa responden dengan pengetahuan dan sikap yang cukup memiliki perilaku penggunaan pembalut yang lebih baik dibandingkan responden yang memiliki sikap yang kurang.

\section{Pembahasan}

Hubungan Pengetahuan dengan Perilaku Pengetahuan remaja putri yang lebih baik memiliki kecenderungan lebih baik pula dalam perilaku penggunaan pembalut. Perbedaan ini erat kaitan dengan terjadinya mekanisme sintesis domain kognitif yang telah berada pada taraf pemahaman yang baik menjadi tindakan yang dikondisikan pada situasi yang sebenarnya. Dengan kata lain pengetahuan merupakan faktor awal dari suatu perilaku yang diharapkan dan pada umumnya memiliki korelasi yang positif dengan tindakan yang ditunjukkan seseorang (Notoatmodjo, 2013).

Komprehensivitas pengetahuan sangat ditentukan oleh mudahnya akses informasi. Dalam penelitian ini terbukti, remaja putri dengan pengetahuan yang berada pada kategori cukup umumnya memahami dengan baik sumber informasi tentang kebersihan organ reproduksi, menstruasi, dan penggunaan pembalut. Mereka tidak membatasi sumber informasi hanya dari orang tua dan guru. Komalasari, (2016) menjelaskan bahwa informasi seputar higienitas menstruasi dapat diakses dengan mudah melalui media informasi seperti internet, majalah, iklan televisi, dan buku-buku tentang kesehatan reproduksi.

Penggunaan pembalut merupakan salah satu komponen kajian kesehatan reproduksi yang menyangkut persolan yang kompleks. Kemudahan akses informasi tidak serta merta memberikan jaminan memadainya pemahaman tentang higienitas menstruasi. Terlebih remaja putri yang cenderung mengembangkan perasa- an sedih, malu, gelisah, khawatir, bingung bahkan takut dalam menjalani menstruasi. Sementara pada remaja putri akan terjadi periode kritis dimana proses menstruasi kali pertama akan terjadi (menarche) (Prabawani, Arifah, \& Zulaicha, 2016).

Luasnya cakupan penggunaan pembalut dan adanya stigma negatif terhadap menstruasi berimbas pada kerentanan remaja putri dalam memahami informasi seputar penggunaan pembalut secara utuh. Temuan dalam penelitian ini menjawab fenomena tersebut dimana secara kuantitas remaja putri yang memahami dengan baik penggunaan pembalut memiliki proporsi yang lebih sedikit. Hasil penelitian ini konsisten dengan penelitian terdahulu, bahwa beberapa indeks pengetahuan tentang kebersihan selama menstruasi menunjukan rendahnya pengetahuan remaja putri, khususnya yang tinggal di daerah pedesaan (Thakre, et al., 2011).

Komponen pengetahuan yang dikembangkan dalam instrumen penelitian ini melibatkan berbagai parameter yang meliputi pengertian, kegunaan, komposisi, dampak penggunaan, aspek penting dalam pembelian dan pemilihan, higienitas, lama penggunaan, penggantian, penyimpanan, dan pembuangan pembalut. Identifikasi lebih lanjut memberi gambaran bahwa remaja putri memiliki pengetahuan yang rendah dalam memahami masa kedaluwarsa, indikator dalam menentukan kualitas, penggantian pembalut dalam rutinitas yang padat, dan periodisasi pemeriksaan pembalut. Tarigan dan Hassan (2013) dalam penelitiannya menemukan kesalahan yang sering dilakukan dalam pemakaian pembalut utamanya pada penggunaan pembalut yang telah kedaluwarsa dan pemakaian pembalut yang terlalu lama.

Pengetahuan atau kognitif merupakan domain yang sangat penting dalam membentuk tindakan seseorang (overt behavior). Perilaku yang didasari oleh pengetahuan akan bertahan lebih lama dibandingkan dengan perilaku yang dilakukan secara intuitif (Wawan \& Dewi, 2015). Remaja putri dengan pengetahuan yang cukup 
dalam penelitian ini telah menunjukkan beberapa parameter perilaku yang baik dalam hal memosisikan pembalut dengan benar, perlakuan pada organ kewanitaan saat akan mengganti pembalut, indikator waktu pembalut harus diganti, kondisi yang mengharuskan penggantian produk pembalut, dan cara memperlakukan pembalut yang telah terpakai.

Remaja putri yang memiliki pengetahuan yang cukup dalam penelitian ini tidak lebih dari $50 \%$. Hal ini berimbas pada perilaku penggunaan pembalut yang kurang tepat oleh sebagian besar responden. Penggunaan pembalut sedikitnya empat buah dalam sehari serta metode pengujian kualitas dan keamanan pembalut belum dilakukan sesuai dengan anjuran. Sementara penggunaan pembalut selama menstruasi harus diganti secara teratur 4-5 kali sehingga paling tidak dibutuhkan empat buah pembalut dalam sehari (Tarigan \& Hassan, 2013).

Perilaku yang kurang baik dalam penggantian pembalut secara periodik berpotensi menyebabkan infeksi jamur dan bakteri (Izzati \& Agustiani, 2015). Masalah ini dapat berkembang menjadi penyakit yang lebih serius seperti keputihan, iritasi kulit genital, alergi, infeksi saluran kemih bahkan berujung pada kanker serviks (Nurlita, 2014).

Perbedaan perilaku pada remaja putri yang berpengetahuan kurang dan cukup tidak menemui kemaknaan yang signifikan, meskipun secara nyata terlihat adanya perbedaan. Penelitian ini sejalan dengan penelitian Walangitan (2010) yang menemukan tidak ada hubungan yang bermakna antara pengetahuan dan perila$\mathrm{ku}$ sehat saat menstruasi. Hal ini disebabkan banyaknya variabel kontributor yang lain yang memengaruhi perilaku penggunaan pembalut. Perilaku penggunaan pembalut tidak hanya menyangkut pengetahuan dan sikap, tetapi melibatkan banyak faktor yang dikategorikan menjadi faktor utama yang meliputi konsep diri, kepercayaan, nilai, dan informasi; faktor demografi yang meliputi status ekonomi, umur, jenis kelamin, dan jumlah keluarga; faktor pendukung yang meliputi sarana dan prasarana; serta faktor pendorong yang meliputi keluarga, teman sebaya, dan lingkungan sekitar (Notoatmodjo, 2013).

Dalam penelitian ini, tidak semua faktor luar yang memengaruhi hubungan pengetahuan dan perilaku diikutsertakan. Data sekunder yang memungkinkan dikompolasi terbatas pada umur dan tingkatan kelas. Variabel tersebut menunjukkan adanya kecenderungan pengetahuan, sikap, dan perilaku pada remaja putri linear dengan umur dan tingkatan kelasnya. Bahkan hubungan tingkatan kelas dan umur dengan pengetahuan dan sikap tidak sebatas menunjukkan perbedaan proporsi, tetapi juga menunjukkan adanya signifikansi secara statistik. Penelitian yang menegakkan hasil penelitian ini adalah Walangitan (2010) yang menemukan bahwa remaja putri yang berumur $\geq 13$ tahun menunjukkan pemahaman dan sikap terhadap higienitas menstruasi yang lebih baik dibandingkan dengan remaja putri yang berumur < 13 tahun.

Variabel luar selain umur dan tingkatan kelas memiliki potensi membentuk perilaku remaja putri dalam penggunaan pembalut. Suryati (2012) dalam penelitiannya berhasil mengidentifikasi beberapa faktor yang berhubungan dengan perilaku menjaga kebersihan organ genitalia termasuk didalamnya penggunaan pembalut. Faktor-faktor tersebut adalah pendidikan orang tua, pengetahuan, sikap, ketersediaan fasilitas alat pembersih, dan dukungan teman sebaya. Lestariningsih (2015) melanjutkan bahwa pengetahuan, sikap, kepercayaan, keterpaparan media massa, pendidikan ibu, dan pekerjaan ibu menjadi faktor penentu terbentuknya kebiasaan yang baik dalam menjaga higienitas menstruasi. Penelitian yang lain oleh Rahayu (2010) mempertegas bahwa perilaku penggunaan pembalut pada remaja putri ditentukan oleh hubungan atau kedekatan ibu dengan remaja putri, kedudukan anak dalam keluarga (urutan di antara anak perempuan), dan uang saku. Dengan demikian pengetahuan dan sikap hanyalah beberapa dari sekian banyak faktor 
yang berasosiasi dengan perilaku penggunaan pembalut pada remaja putri.

Meskipun terdapat banyak faktor yang dihubungkan dengan pembentukan perilaku penggunaan pembalut pada remaja putri, tetapi variabel pengetahuan masih dianggap kontributor utama yang secara langsung memengaruhi perilaku. Hanya saja pengetahuan yang baik tidak mutlak selalu bersesuain dengan perilaku yang baik. Ayuningtyas, (2011) mengidentifikasi bahwa lingkungan keluarga terutama ibu merupakan faktor paling dominan yang memengaruhi perilaku penggunaan pembalut. Remaja putri akan belajar dan cenderung menganut kebiasaan yang lazim dilakukan oleh ibu atau kakak perempuannya sehingga walaupun mayoritas remaja putri berada pada kategori pengetahuan yang kurang, tetapi boleh jadi menunjukkan perilaku yang baik, begitupun sebaliknya. Hal ini cukup beralasan sebab kebiasaan dan budaya dari ibu melekat erat pada perilaku anak.

\section{Hubungan Sikap dengan Perilaku Peng- gunaan Pembalut pada Remaja Putri. Hu-} bungan yang sama diperoleh dalam variabel sikap dengan perilaku penggunaan pembalut. Sikap remaja putri menunjukkan adanya perbedaan dalam praktik penggunaan pembalut dimana remaja putri dengan sikap yang lebih baik umumnya menunjukkan perilaku penggunaan pembalut yang lebih baik pula. Hal ini dibuktikan dengan memadainya perilaku remaja putri yang memiliki sikap yang cukup pada pertanyaan-pertanyaan yang bersifat $f a$ vorable, antara lain dalam memosisikan pembalut dengan benar, perlakuan pada organ kewanitaan saat akan mengganti pembalut, indikator kapan pembalut harus diganti, kondisi yang mengharuskan penggantian produk pembalut, dan cara memperlakukan pembalut yang telah terpakai.

Temuan oleh Nurhayati (2013) mengindikasikan bahwa remaja putri cenderung mengembangkan sikap yang kurang mendukung terhadap beberapa komponen higienitas mens- truasi. Dalam penelitian ini lebih dari setengah responden merespon tidak setuju bahkan sangat tidak setuju pada komponen pertanyaan yang mengobservasi sikap responden terkait adanya dampak negatif penggunaan pembalut terhadap kesehatan. Kondisi ini dipertegas dengan kebiasaan remaja putri yang jarang melakukan penggantian pembalut utamanya saat berada di lingkungan sekolah, dibuktikan dengan penggunaan pembalut yang kurang dari 4 buah dalam sehari. Dampak negatif dari kebiasaan ini berimplikasi pada kurang terjaganya kelembaban organ kewanitaan dan dalam jangka waktu yang lama dapat mengakibatkan terjadinya infeksi (Lestariningsih, 2015). Sementara infeksi alat reproduksi mempunyai konsekuensi yang buruk pada masa yang akan datang bahkan dapat berdampak seumur hidup, seperti kemandulan yang imbasnya berujung pada menurunnya kualitas hidup individu yang bersangkutan (Indah, 2012).

Sikap kurang dalam penggunaan pembalut yang ditunjukkan remaja putri tidak terlepas dari masih rendahnya pengetahuan higienitas menstruasi yang dimiliki. Sesuai dengan teori Notoatmodjo (2013) dikatakan bahwa terbentuknya perilaku dalam menjaga kebersihan organ genital dimulai pada domain kognitif, dalam arti remaja putri tahu terlebih dahulu terhadap stimulus yang berupa materi atau objek dari luar. Stimulus tersebut akan menghasilkan pengetahuan baru yang dalam rangkaiannya akan menimbulkan respon batin dalam bentuk sikap terhadap objek yang diketahui.

Asumsi remaja putri dengan sikap yang cukup memiliki perilaku penggunaan pembalut yang lebih baik belum dapat digeneralisasi sepenuhnya. Hal ini disebabkan oleh rasio remaja putri yang memiliki sikap yang baik dengan remaja putri yang memiliki perilaku penggunaan pembalut yang baik dalam penelitian ini berada pada kondisi yang timpang. Sekalipun sikap dianggap sebagai predisposisi evaluatif yang banyak menentukan cara bertindak, akan tetapi sikap dan tindakan nyata seringkali jauh berbeda. Hal ini dikarenakan tindakan nyata tidak 
hanya ditentukan oleh sikap semata, tetapi berbagai faktor eksternal lainnya. Hasil penelitian ini membuktikan bahwa premis tersebut dimana sikap tidak menunjukkan adanya korelasi dengan perilaku penggunaan pembalut (Azwar, 2011).

Lebih lanjut Walangitan (2010) melakukan penelitian pada remaja putri SMPN dan MTs Kota Depok untuk memahami hubungan sikap dengan perilaku higienitas menstruasi. Sejalan dengan penelitian ini, tidak ditemukan adanya hubungan yang bermakna antara sikap dan perilaku sehat yang dipraktikkan remaja putri saat menstruasi. Meski demikian, Walangitan dalam studinya menemukan bahwa proporsi perilaku sehat saat menstruasi lebih banyak ditunjukkan pada siswi yang memiliki sikap yang baik dibandingkan siswi yang memiliki sikap yang kurang.

Tidak ditemukannya keterkaitan sikap dengan perilaku penggunaan pembalut didasari oleh banyaknya variabel yang turut menunjukkan asosiasi baik terhadap variabel sikap, perilaku, maupun keduanya. Salah satu faktor yang dipertimbangkan membentuk perilaku remaja putri dalam penggunaan pembalut adalah lingkungan pergaulan siswi di sekolah atau lingkungan di sekitar tempat tinggal (Komalasari, 2016). Nurlita (2014) menambahkan dalam penelitiannya bahwa faktor psikologi yang secara tidak langsung menunjukkan hubungan dengan sikap dan perilaku remaja putri dalam higienitas menstruasi antara lain rasa rendah diri, tekanan teman sebaya, tindak kekerasan di rumah atau lingkungan, dan ketidakharmonisan orang tua.

Keterbatasan dalam penelitian ini berupa sample size yang kecil sehingga memengaruhi kekuatan penelitian dalam menggambarkan hubungan variabel pengetahuan, sikap, dan perilaku penggunaan pembalut. Selain itu, instrumen pengumpulan data menggunakan kuesioner bersifat subjektif sehingga kebenaran data sangat bergantung pada kejujuran responden.

\section{Kesimpulan}

Penelitian ini memberi temuan bahwa pengetahuan dan sikap tidak selalu menjadi faktor yang menginisiasi pembentukan perilaku. Meskipun terdapat perbedaan antara pengetahuan dan sikap berdasarkan kategori kurang dan cukup dalam perilaku penggunaan pembalut pada remaja putri di SMP Negeri X Tondong Tallasa Kabupaten Pangkep, namun tidak ditemukan ada kemaknaan secara statistik. Tidak ditemukannya korelasi antara pengetahuan dan sikap dengan perilaku penggunaan pembalut pada remaja putri di daerah pedesaan Kabupaten Pangkep mengisyaratkan banyaknya variabel kontributor lain yang berpotensi mengganggu hubunganvariabel utama yang diteliti. Pada penelitian ini variabel statis berupa umur dan tingkatan kelas secara nyata menunjukkan asosiasi dengan pengetahuan dan sikap remaja putri dalam penggunaan pembalut.

Dengan demikian, dalam tatanan praktis intervensi perilaku higienitas dan kesehatan organ reproduksi pada remaja putri sebaiknya tidak hanya dititikberatkan pada perubahan aspek pengetahuan dan sikap, tetapi dengan mempertimbangkan variabel kontributor yang lain. Selain itu, intensitas paparan informasi tentang higienitas dan kesehatan organ reproduksi pada siswi Sekolah Menengah Pertama/ Sederajat yang menduduki kelas VII perlu ditingkatkan lagi utamanya dalam pemilihan dan penilaian produk pembalut yang aman; durasi penggantian pembalut; dan dampak penggunaan pembalut yang kurang tepat. Pada penelitian berikutnya hendaknya mengikutsertakan variabel kontributor yang lain dengan melibatkan sampel penelitian yang lebih besar untuk mengonfirmasi hubungan pengetahuan dan sikap dengan perilaku penggunaan pembalut pada remaja putri (EH, YA, TN). 


\section{Referensi}

Andriyani, A. (2013). Panduan kesehatan wanita: Haid, hamil, melahirkan, nifas, menyusui. Solo: As-Salam Publishing.

Ayuningtyas, D.N. (2011). Hubungan antara pengetahuan dan perilaku menjaga kebersihan genitalia eksterna dengan kejadian keputihan pada siswi SMA Negeri 4 Semarang. Institutional Repository (UNDIP-IR). Retrieved from http://eprints.undip.ac.id/32942/

Azwar, S. (2011). Sikap manusia teori dan pengukurannya (2 Ed.). Yogyakarta: Pustaka Pelajar.

Badan Penelitian dan Pengembangan Kesehatan (Balitbangkes). (2013). Riset kesehatan dasar (Riskesdas 2013). Jakarta: Kementerian Kesehatan Republik Indonesia.

Dinas Kesehatan Kabupaten Pangkep. (2014). Profil kesehatan kabupaten Pangkep tahun 2013. Kabupaten Pangkep: Dinas Kesehatan Kabupaten Pangkep.

Himawati, L., \& Sahara, R. (2016). Personal hygiene menstruasi pada remaja putri pada siswa kelas XI di SMA Muhammadiyah Purwodadi. E-journal STIKES An-Nur Purwodadi, 40-51.

Indah, F.T.N. (2012). Kejadian pruritus vulvae saat menstruasi pada remaja putri (Studi pada siswi SMAN 1 Ngimbang Kabupaten Lamongan). Repository Universitas Airlangga. Retrieved from repository. unair.ac..id/23638/

Izzati, W., \& Agustiani, R. (2015). Hubungan pengetahuan dengan pelaksanaan personal hygiene genitalia saat menstruasi pada remaja putri kelas IX SMP Negeri 4 Bukittinggi. Jurnal Ilmu Kesehatan 'Afiyah, 2 (1). Retrieved from http:// ejournal.stikesyarsi.ac.id/index.php/JAV1 N1/article/view/31
Komalasari, T. (2016). Faktor-faktor yang berhubungan dengan perilaku personal hygiene siswa kelas VII-VIII pada saat menarche di SMPN 2 Majalengka Tahun 2015. Jurnal Keperawatan dan Kesehatan MEDISINA AKPER YPIB Majalengka, II (3). Retrieved from http://ejournal.akper ypib.ac.id/index.php/tag/perilaku-personalhygiene/

Kusmiran, E. (2011). Kesehatan reproduksi remaja dan wanita. Jakarta: Salemba Medika.

Lestariningsih, S. (2015). Faktor-faktor yang berhubungan dengan praktik higiene menstruasi. Jurnal Kesehatan Metro Sai Wawai, VIII (2), 14-22.

Manuaba, I.A.C., Manuaba, I.B.G.F., \& Manuaba, I.B.G. (2015). Buku ajar patologi obstetri untuk mahasiswa kebidanan. Jakarta: Buku Kedokteran EGC.

Notoatmodjo, S. (2013). Promosi kesehatan teori dan aplikasi (Edisi Revisi). Jakarta: Rineka Cipta.

Nurhayati, A. (2013). Hubungan pengetahuan, sikap, dan perilaku vaginal hygiene terhadap kejadian keputihan patologis pada remaja putri usia 13-17 tahun di Daerah Pondok Cabe Ilir (Skripsi). Universitas Islam Negeri Syarif Hidayatullah, Jakarta. Retrieved from http: //repository.uinjkt.ac.id/dspace/handle/123 $456789 / 26343$

Nurlita, W. (2014). Gambaran tingkat pengetahuan dan perilaku menjaga kebersihan organ genetalia eksterna pada siswi MI Pembangunan (Skripsi). Universitas Islam Negeri Syarif Hidayatullah, Jakarta. Retrieved from http: //repository.uinjkt.ac.id/dspace/handle/123 $456789 / 24105$

Prabawani, C.R., Arifah, S., \& Zulaicha, E. (2016). Gambaran perilaku remaja putri pada masa pubertas di Desa Tanjungrejo Grobogan. E-Prints Universitas Muhammadiyah 
Surakarta. Retrieved from http://eprints. ums.ac.id/41540/

Rahayu, L.P. (2010). Perilaku penggunaan pembalut pada mahasiswi (Skripsi). Institut Pertanian Bogor, Bogor. Retrieved from http://repository.ipb.ac.id/xmlui/hand le/123456789/27286

Suryati, B. (2012). Perilaku kebersihan remaja saat menstruasi. Jurnal Health Quality, 3(1), $54-65$.

Syatriani, S. (2011). Faktor risiko kanker serviks di Rumah Sakit Umum Pemerintah Dr. Wahidin Sudirohusodo Makassar, Sulawesi Selatan. Kesmas: National Public Health Journal, 5 (6), 283-288. https://doi.org/10.21109/kesmas.v5i6.125

Tarigan, W.J., \& Hassan. (2013). Gambaran tentang hubungan pengetahuan dan sikap dengan praktek higiene menstruasi pada remaja putri kelas 7 dan 8 di SMPN 141 Jakarta Selatan Tahun 2012. OPACUniversitas Indonesia Library. Retrieved from http://lib.ui.ac.id/detail?id=20332044 \&lokasi=lokal

Thakre, S.B., Thakre, S.S., Reddy, M., Rathi, N., Pathak, K., \& Ughade, S. (2011). Menstrual hygiene: Knowledge and practice among adolescent school girls of Saoner, Nagpur District. J Clin Diagn Res, 5(5), 1027-1033.
Walangitan, V.R.J. (2010). Faktor-faktor yang berhubungan dengan perilaku sehat menstruasi remaja putri siswi SMP Negeri dan MTs Kota Depok Tahun 2010 (Skripsi, tidak dipublikasi). Universitas Indonesia, Depok.

Wawan, A., \& Dewi, M. (2015). Teori \&pengukuran pengetahuan, sikap, dan perilaku manusia. Yogyakarta: Nuha Medika.

World Health Organization (WHO). (2014). Comprehensive cervical cancer control: A guide to essential practice. Retrieved from http://apps.who.int/iris/bitstream/10665/14 4785/1/9789241548953_eng.pdf?ua=1

YLKI. (2015). Pengujian kadar klor pada pembalut dan pantyliner (Laporan Penelitian). Jakarta: Yayasan Lembaga Konsumen Indonesia. Retrieved from https://ylki.or.id/2015/07/hasil-uji-ylki-pe mbalut-dan-pantyliner-mengandung-klor/ 